\title{
Effect of Nutrient Levels and Plant Growth Regulators on Harvest Index and Economics of Soybean (Glycine max)
}

\author{
S. M. Manu ${ }^{1^{*}}$, S. P. Halagalimath ${ }^{2}$, H. T. Chandranath ${ }^{3}$ and B. D. Biradar ${ }^{4}$ \\ ${ }^{1}$ Division of Agronomy, ICAR-Indian Agricultural Research Institute, \\ New Delhi-110012 (India) \\ ${ }^{2}$ Directorate of Extension, ${ }^{3}$ Directorate of Post Graduate Studies, University of Agricultural \\ Sciences, Dharwad, Karnatka-580005 (India) \\ ${ }^{4}$ College of Agriculture, Dharwad, University of Agricultural Sciences, \\ Dharwad, Karnataka-580005 (India) \\ *Corresponding author
}

\section{A B S T R A C T}

\begin{tabular}{|l|}
\hline Ke y w o r d s \\
Chlormequat \\
chloride, Ethrel, \\
$\begin{array}{l}\text { Harvest index, Net } \\
\text { return, BC ratio }\end{array}$ \\
\hline Article Info \\
\hline $\begin{array}{l}\text { Accepted: } \\
\text { 05 February } 2020 \\
\text { Available Online: } \\
\text { 10 March } 2020\end{array}$ \\
\hline
\end{tabular}

A field experiment was conducted to study the influence nutrient levels and plant growth regulators on harvest index and economics of soybean [Glycine max (L.) Merrill] during kharif 2017. The experiment was laid out using randomized complete block design (factorial concept) with 14 treatments including control and replicated thrice. The treatments consisted of two nutrient levels $125 \% \mathrm{RDF}$ and $100 \% \mathrm{RDF}$, six plant growth regulator (PGR) dosages: salicylic acid @ 50 and 100 ppm, ethrel @ 100 and 200 ppm, chlormequat chloride (CCC) @ 250 and 500 ppm; independent control: RPP, without PGR spray and RPP $+\mathrm{KNO}_{3} @ 1 \%$. PGRs were sprayed at 25 and 40 DAS. Results shows that application of $125 \%$ RDF + chlormequat chloride @ 500 ppm at 25 and 40 days after sowing (DAS) as foliar spray. The results revealed that application of $125 \% \mathrm{RDF}+$ chlormequat chloride @ 500 ppm was optimum to get higher yield $\left(26.31 \mathrm{q} \mathrm{ha}^{-1}\right)$, harvest index $\left(46.6 \%\right.$ ) and net return (₹ 64,714 ha ${ }^{-1}$ ) with B:C (3.15), followed by $125 \%$ RDF + ethrel @ 200 ppm (23.70 q ha ${ }^{-1}, 46.03 \%$, ₹ 56,146 and 2.92, respectively).

\section{Introduction}

The soybean [Glycine max (L.) Merrill] is also called as "Miracle crop" is a source of protein for human beings, animal feeds and many prepackaged meals. It is excellent in its nutritive value with enhanced protein (40-42 $\%)$ and oil $(20 \%)$ content and is also rich in vitamins, minerals, salts and other essential amino acids (Dass et al., 2018). Globally it occupies an area of 120.30 million hectares with production of 351.32 million tonnes and 
productivity of $2.92 \mathrm{t} \mathrm{ha}^{-1}$ (Anon., 2017). In India it is grown over an area of 11.25 million hectare with production of 11.73 million tonnes and productivity of $1042 \mathrm{~kg} \mathrm{ha}^{-1}$ (Anon., 2018). Soybean is characterized by prolific flower production with an extremely low proportion of pod set. The extent of flower shedding is said to be 60-92\% in soybean (Nahar and Ikeda, 2002), which causes low yield. Plant growth regulators are well known to improve the source-sink connection and encourage the translocation of photo-assimilates thereby helping in effective flower formation, fruit, and seed development and ultimately increase the yield of crops. Some of the growth regulators like salicylic acid, ethrel and chlormequat chloride (cycocel) may play a greater role to increase the growth and yield attributing characters of soybean. Salicylic acid is an endogenous growth regulator of phenol nature, which participates in regulation of physiological processes in plant, stomata closure, ion uptake, inhibition of ethylene biosynthesis, transpiration and stress tolerance (Khan et al., 2003). And also its application increase carbon dioxide $\left(\mathrm{CO}_{2}\right)$ and assimilation and photosynthetic rate, thus increasing dry matter. Ethylene released from ethrel (2Chloro ethyl phosphonic acid) could possibly be utilized for promoting pod growth and early pod development in chickpea and tomato are related to higher ethylene levels, thus decreasing flower and pod shedding and thereby reducing abscission and improving better pod set. Ethrel induced increase in cell division, resulting in increased fruit size and yield have been reported in tomato fruits. Chlormequat chloride (CCC) or Cycocel is a plant growth regulator and known as antagonist of the plant hormone gibberellin. It acts by inhibiting gibberellin biosynthesis, reducing intermodal growth to give stouter stems, enhanced root growth, causing early fruit set and increasing seed set in plants, which leads to improve in the harvest index of the crop (Manu et al., 2020). Sanjay (2017) also reported that foliar spray of chlormequat chloride $50 \%$ SL @ $500 \mathrm{~g} \mathrm{ha}^{-1}$ at flowering and pod formation stage resulted in maximum net income and $\mathrm{BC}$ ratio.

Therefore, the present investigation was aimed to evaluate effect nutrient levels and plant growth regulators on harvest index and economics of soybean [Glycine max (L.) Merrill].

\section{Materials and Methods}

A field study was conducted at University of Agricultural Sciences, Dharwad, Karnataka (India) on medium deep black soil during kharif 2017. The experiment was laid out using randomized complete block design (factorial concept) with nutrient levels $\left(\mathrm{N}_{1}\right)$ : $100 \%$ RDF (40:80:25 N:P $\mathrm{O}_{5}: \mathrm{K} 2 \mathrm{O} \mathrm{kg} \mathrm{ha}{ }^{-1}$ ) and $\left(\mathrm{N}_{2}\right): \quad 125 \%$ RDF $\quad(50: 100: 31.2$ $\left.\mathrm{N}: \mathrm{P}_{2} \mathrm{O}_{5}: \mathrm{K}_{2} \mathrm{O} \mathrm{kg} \mathrm{ha}{ }^{-1}\right)$; Plant growth regulators $\left(\mathrm{G}_{1}\right)$ : Salicylic acid @ 50 ppm, $\left(\mathrm{G}_{2}\right)$ : Salicylic acid@100 ppm, $\left(\mathrm{G}_{3}\right)$ : Ethrel @ 100 ppm, $\left(\mathrm{G}_{4}\right)$ : Ethrel @ $200 \mathrm{ppm},\left(\mathrm{G}_{5}\right)$ : Chlormequat chloride@250 ppm and $\left(\mathrm{G}_{6}\right)$ : Chlormequat chloride @ 500 ppm; Controls $\left(\mathrm{C}_{1}\right)$ : Independent control RPP-without plant growth regulator spray and $\left(\mathrm{C}_{2}\right): \mathrm{RPP}+\mathrm{KNO}_{3}$ @ $1 \%$ foliar spray. The experiment consisted of twelve treatment combinations with two control treatments (Table 1) and replicated thrice. The $\mathrm{N}, \mathrm{P}_{2} \mathrm{O}_{5}$ and $\mathrm{K}_{2} \mathrm{O}$ were applied as per the treatments to each plot in the form of Urea, SSP and MOP at the time of sowing along with gypsum at the rate of $100 \mathrm{~kg} \mathrm{ha}^{-1}$. Plant growth regulators were sprayed in different concentration as per the treatment at 25 and 40 DAS on $1^{\text {st }}$ Aug 2017 and $16^{\text {th }}$ Sept 2017, respectively. During the crop growth period, a total rainfall of $582.8 \mathrm{~mm}$ was received which was optimum for good growth and higher yield. The soil of the experimental site was clay with $\mathrm{pH}$ of 7.02 and electrical conductivity of $0.29 \mathrm{dS} \mathrm{m}$. The soil was 
medium in organic carbon $(0.51 \%)$ and low in available nitrogen $(258.5 \quad \mathrm{~kg}$ $\left.\mathrm{ha}^{-1}\right)$ and medium in available $\mathrm{P}\left(32.5 \mathrm{~kg} \mathrm{ha}^{-1}\right)$ and available $\mathrm{K}\left(285.5 \mathrm{~kg} \mathrm{ha}^{-1}\right)$. The land was ploughed by tractor once after the harvest of previous crop followed by harrowing twice. At the time of sowing, the land was prepared to a fine seed bed, FYM was added at the rate of 5 tonnes per hectare and the plots were laid out as per the plan of layout of the experiment. Gross plot size and net plot size were $4.0 \times 3.6 \mathrm{~m}$ and $3.8 \times 3.0 \mathrm{~m}$, respectively. Soybean variety $D S b-21$ seeds were treated using $1250 \mathrm{~g}$ each Rhizobium and PSB per hectare seeds. Two seeds per hill were dibbled $5 \mathrm{~cm}$ deep in furrows at a spacing of $30 \times 10 \mathrm{~cm}$ on 06 th July 2017 . The seed rate used was $62.5 \mathrm{~kg} \mathrm{ha}{ }^{-1}$. Two protective irrigations were given to the crop at $2^{\text {nd }}$ and $4^{\text {th }}$ week of August 2017 as rainfall received was less. Agronomic parameters were recorded from randomly selected five plants in net plot area at 30 and 60 DAS and at harvest. Seeds harvested from net plot were dried and weighed. On the basis of seed weight per net plot, the seed yield per ha was computed and expressed in $\mathrm{kg}$ per ha and converted to $\mathrm{q}$ per ha. The total biological portion from above ground portion from net plot at harvest was weighed after complete sun drying and haulm yield per ha was worked out by deducting the seed yield and expressed as $\mathrm{kg}$ per ha and converted to q per ha. Harvest index is defined as the ratio of economic yield to biological yield and expressed in percentage. Harvest index was estimated as per the formula suggested by (Donald, 1962).

$$
\mathrm{HI}(\%)=\frac{\text { Economic yield }\left(\mathrm{kg} \mathrm{ha}^{-1}\right)}{\text { Pod yield }+ \text { Haulm yield }\left(\mathrm{kg} \mathrm{ha}^{-1}\right)} \times 100
$$

The income from main product (seed) and byproduct (haulm) of soybean was considered for accounting gross return. The market price prevailed at the time of selling seed ( $₹$ 3,600 $\mathrm{q}^{-1}$ ) and haulm (₹ $75 \mathrm{q}^{-1}$ ) was considered to calculate the gross return $\left(₹ \mathrm{ha}^{-1}\right)$. Net return was calculated by subtracting the cost of cultivation ( $₹ \mathrm{ha}^{-1}$ ) from the gross return ( $₹$ $\left.\mathrm{ha}^{-1}\right)$. The ratio of net return and cost of cultivation (Table 2 and 3) was worked out for each treatment and was given as benefit cost ratio ( $\mathrm{B}: \mathrm{C})$ to compare the performance of different treatments.

$\mathrm{B}: \mathrm{C}=\frac{\text { Gross return }\left(₹ \mathrm{ha}^{-1}\right)}{\text { Cost of cultivation }\left(₹ \mathrm{ha}^{-1}\right)}$

The experimental data was statistically analyzed based on mean values obtained by using a standard method of ANOVA (analysis of variance). The level of significance used in ' $\mathrm{F}$ ' and ' $\mathrm{T}$ ' test was $\mathrm{P}=0.05$ (Gomez and Gomez, 1984).

\section{Results and Discussion}

\section{Harvest index}

The data on harvest index (\%) as influenced by nutrient levels and plant growth regulators are presented in Table 1 . With respect to different levels of nutrient on harvest index, application of $125 \%$ RDF recorded significantly recorded higher harvest index (45.25\%) compared to $100 \% \operatorname{RDF}$ (44.38). Among the different plant growth regulators, chlormequat chloride @ 500 ppm recorded significantly harvest index $(46.42 \%)$ followed by ethrel @ 200 ppm (45.49\%) as compared to rest of the treatments. Within the interactions, significantly higher harvest index $(46.61 \%)$ recorded with the combined application of $125 \% \mathrm{RDF}+$ chlormequat chloride@ 500 ppm, follwed by application of $125 \%$ RDF + ethrel @ 200 ppm (46.52\%) as compared to other treatment combinations and control $\left[\mathrm{C}_{1}\right](42.04 \%)$. 
Table.1 Effect of nutrient levels and plant growth regulators on seed yield, haulm yield, harvest index and net return and $\mathrm{BC}$ ratio of soybean

\begin{tabular}{|c|c|c|c|c|c|c|c|}
\hline Treatments & $\begin{array}{c}\text { Seed } \\
\text { yield } \\
\left(\mathbf{q} \mathbf{h a}^{-1}\right)\end{array}$ & $\begin{array}{c}\text { Haulm } \\
\text { yield } \\
\left(\mathbf{q} \mathrm{ha}^{-1}\right)\end{array}$ & $\begin{array}{c}\text { Harvest } \\
\text { index } \\
(\%)\end{array}$ & $\begin{array}{c}\text { Cost of } \\
\text { cultivation } \\
\left(₹ \text { ha }^{-1}\right)\end{array}$ & $\begin{array}{c}\text { Gross } \\
\text { return } \\
\left(₹ \mathbf{h a}^{-1}\right)\end{array}$ & $\begin{array}{c}\text { Net } \\
\text { return } \\
\left(₹ \mathbf{h a}^{-1}\right)\end{array}$ & $\mathrm{B}: \mathrm{C}$ \\
\hline \multicolumn{8}{|l|}{ Nutrient levels } \\
\hline $\mathbf{N}_{1}$ & 20.46 & 25.61 & 44.38 & 27,781 & 73,677 & 45,896 & 2.65 \\
\hline $\mathbf{N}_{2}$ & 22.34 & 26.66 & 45.25 & 29,203 & 80,436 & 51,233 & 2.75 \\
\hline S. Em. \pm & 0.14 & 0.23 & 0.27 & - & 489 & 489 & 0.02 \\
\hline C. D. at $5 \%$ & 0.40 & 0.68 & 0.80 & - & 1435 & 1435 & 0.05 \\
\hline \multicolumn{8}{|c|}{ Plant growth regulators } \\
\hline $\mathbf{G}_{1}$ & 19.81 & 25.09 & 44.14 & 28,092 & 71,341 & 43,249 & 2.54 \\
\hline $\mathbf{G}_{2}$ & 20.43 & 25.45 & 44.53 & 28,631 & 73,585 & 44,954 & 2.57 \\
\hline $\mathbf{G}_{3}$ & 19.61 & 25.15 & 43.79 & 27,994 & 70,603 & 42,609 & 2.52 \\
\hline $\mathbf{G}_{4}$ & 22.67 & 27.15 & 45.49 & 28,436 & 81,627 & 53,191 & 2.87 \\
\hline $\mathbf{G}_{5}$ & 21.12 & 26.34 & 44.51 & 28,451 & 76,058 & 47,607 & 2.67 \\
\hline $\mathbf{G}_{6}$ & 24.75 & 28.55 & 46.42 & 29,351 & 89,128 & 59,777 & 3.03 \\
\hline S. Em. \pm & 0.24 & 0.40 & 0.47 & - & 847 & 847 & 0.03 \\
\hline C. D. at $5 \%$ & 0.69 & 1.18 & 1.38 & - & 2485 & 2485 & 0.09 \\
\hline \multicolumn{8}{|l|}{ Interaction } \\
\hline $\mathbf{N}_{1} \mathbf{G}_{1}$ & 19.46 & 24.33 & 44.44 & 27,391 & 70,068 & 42,677 & 2.56 \\
\hline $\mathbf{N}_{1} \mathbf{G}_{2}$ & 19.74 & 25.16 & 43.98 & 27,821 & 71,011 & 43,190 & 2.55 \\
\hline $\mathbf{N}_{\mathbf{1}} \mathbf{G}_{\mathbf{3}}$ & 18.58 & 24.49 & 43.13 & 27,271 & 66,912 & 39,641 & 2.45 \\
\hline $\mathbf{N}_{1} \mathbf{G}_{4}$ & 21.66 & 27.05 & 44.47 & 27,671 & 77,907 & 50,236 & 2.82 \\
\hline $\mathbf{N}_{1} \mathbf{G}_{5}$ & 20.18 & 25.45 & 44.21 & 27,771 & 72,565 & 44,794 & 2.61 \\
\hline$N_{1} G_{6}$ & 23.26 & 27.20 & 46.03 & 28,671 & 83,511 & 54,840 & 2.91 \\
\hline $\mathbf{N}_{2} \mathbf{G}_{1}$ & 20.16 & 25.84 & 43.84 & 28,791 & 72,613 & 43,822 & 2.52 \\
\hline $\mathbf{N}_{2} \mathbf{G}_{2}$ & 21.22 & 25.74 & 45.08 & 29,351 & 76,069 & 46,718 & 2.59 \\
\hline $\mathbf{N}_{2} \mathbf{G}_{3}$ & 20.63 & 25.80 & 44.46 & 28,716 & 74,293 & 45,577 & 2.60 \\
\hline $\mathbf{N}_{2} \mathbf{G}_{4}$ & 23.70 & 27.25 & 46.52 & 29,201 & 85,347 & 56,146 & 2.92 \\
\hline $\mathbf{N}_{2} \mathbf{G}_{5}$ & 22.09 & 27.23 & 44.80 & 29,132 & 79,551 & 50,419 & 2.73 \\
\hline $\mathbf{N}_{2} \mathbf{G}_{6}$ & 26.31 & 29.89 & 46.61 & 30,031 & 94,745 & 64,714 & 3.15 \\
\hline S. Em. \pm & 0.33 & 0.57 & 0.67 & - & 1198 & 1198 & 0.04 \\
\hline C. D. at $5 \%$ & 0.98 & NS & 0.80 & - & 3514 & 3515 & NS \\
\hline \multicolumn{8}{|l|}{ Control } \\
\hline $\mathbf{C}_{1}$ & 17.09 & 22.36 & 42.04 & 26,571 & 61,546 & 34,675 & 2.34 \\
\hline $\mathbf{C}_{2}$ & 18.04 & 23.10 & 42.86 & 27,321 & 64,967 & 37,646 & 2.38 \\
\hline S. Em. \pm & 0.35 & 0.58 & 0.71 & - & 1244 & 1244 & 0.04 \\
\hline C. D. at $5 \%$ & 1.00 & 1.67 & 2.07 & - & 3616 & 3616 & 0.13 \\
\hline
\end{tabular}

\begin{tabular}{|c|c|c|}
\hline $\mathrm{N}_{1}=100 \%$ RDF (40:80:25 N:P $\left.\mathrm{O}_{5}: \mathrm{K}_{2} \mathrm{O} \mathrm{kg} \mathrm{ha}^{-1}\right)$ & $\mathbf{G}_{3}=$ Ethrel @ 100 ppm & $\mathrm{C}_{1}=\mathrm{RPP}$, without plant growth regulator \\
\hline $\mathrm{N}_{2}=125 \% \operatorname{RDF}\left(50: 100: 31.25 \mathrm{~N}: \mathrm{P}_{2} \mathrm{O}_{5}: \mathrm{K}_{2} \mathrm{O} \mathrm{kg} \mathrm{ha}{ }^{-1}\right)$ & $\mathrm{G}_{4}=$ Ethrel @ 200 ppm & $\mathrm{C}_{2}=\mathrm{RPP}+\mathrm{KNO}_{3} @ 1 \%$ (Foliar spray) \\
\hline $\mathbf{G}_{1}=$ Salicylic acid @ 50 ppm & $\mathrm{G}_{5}=$ Chlormequat chloride @ 250 ppm & $\mathrm{RDF}=$ Recommended dose of fertilizer \\
\hline $\mathbf{G}_{2}=$ Salicylic acid @ 100 ppm & $\mathrm{G}_{6}=$ Chlormequat chloride @ 500 ppm & $\mathrm{RPP}=$ Recommended package of practice \\
\hline Note: Spray at 25 and 40 DAS & NS $=$ Non - significant & $\mathrm{B}: \mathrm{C}=$ Benefit cost ratio \\
\hline
\end{tabular}


Table.2 Treatment-wise details of cost of cultivation (₹ ha ${ }^{-1}$ ) of soybean per hectare basis during kharif-2017

\begin{tabular}{|c|c|c|c|c|c|c|c|c|c|c|c|c|c|c|}
\hline Particulars & $\mathbf{T}_{1}$ & $\mathbf{T}_{2}$ & $\mathbf{T}_{3}$ & $\mathbf{T}_{4}$ & $\mathbf{T}_{5}$ & $\mathbf{T}_{6}$ & $\mathbf{T}_{7}$ & $\mathbf{T}_{8}$ & $\mathbf{T}_{9}$ & $\mathbf{T}_{10}$ & $\mathbf{T}_{11}$ & $T_{12}$ & $\mathbf{T}_{13}$ & $\mathbf{T}_{14}$ \\
\hline \multicolumn{15}{|c|}{ Land preparation } \\
\hline Ploughing (tractor) & 1,500 & 1,500 & 1,500 & 1,500 & 1,500 & 1,500 & 1,500 & 1,500 & 1,500 & 1,500 & 1,500 & 1,500 & 1,500 & 1,500 \\
\hline Harrowing (bullock) & 1,200 & 1,200 & 1,200 & 1,200 & 1,200 & 1,200 & 1,200 & 1,200 & 1,200 & 1,200 & 1,200 & 1,200 & 1,200 & 1,200 \\
\hline \multicolumn{15}{|c|}{ Seeds and sowing } \\
\hline Sowing & 1,700 & 1,700 & 1,700 & 1,700 & 1,700 & 1,700 & 1,700 & 1,700 & 1,700 & 1,700 & 1,700 & 1,700 & 1,700 & 1,700 \\
\hline Seed cost & 4,100 & 4,100 & 4,100 & 4,100 & 4,100 & 4,100 & 4,100 & 4,100 & 4,100 & 4,100 & 4,100 & 4,100 & 4,100 & 4,100 \\
\hline $\begin{array}{l}\text { Seed treatment } \\
\text { (Rhizobium and } P S B \text { ) }\end{array}$ & 200 & 200 & 200 & 200 & 200 & 200 & 200 & 200 & 200 & 200 & 200 & 200 & 200 & 200 \\
\hline \multicolumn{15}{|c|}{ Fertilizer cost } \\
\hline FYM $\left(5 \mathrm{t} \mathrm{ha}^{-1}\right)$ & 2,500 & 2,500 & 2,500 & 2,500 & 2,500 & 2,500 & 2,500 & 2,500 & 2,500 & 2,500 & 2,500 & 2,500 & 2,500 & 2,500 \\
\hline Urea & 540 & 540 & 540 & 540 & 540 & 540 & 675 & 675 & 675 & 675 & 675 & 675 & 540 & 540 \\
\hline SSP & 4,150 & 4,150 & 4,150 & 4,150 & 4,150 & 4,150 & 5,187 & 5,187 & 5,187 & $5,187.5$ & 5,187 & 5,187 & 4,150 & 4,150 \\
\hline MOP & 751 & 751 & 751 & 751 & 751 & 751 & 938 & 938 & 938 & 938 & 938 & 938 & 751 & 751 \\
\hline Application cost & 1,200 & 1,200 & 1,200 & 1,200 & 1,200 & 1,200 & 1,200 & 1,200 & 1,200 & 1,200 & 1,200 & 1,200 & 1,200 & 1,200 \\
\hline Intercultivation & 1,200 & 1,200 & 1,200 & 1,200 & 1,200 & 1,200 & 1,200 & 1,200 & 1,200 & 1,200 & 1,200 & 1,200 & 1,200 & 1,200 \\
\hline Hand wedding & 900 & 900 & 900 & 900 & 900 & 900 & 900 & 900 & 900 & 900 & 900 & 900 & 900 & 900 \\
\hline \multicolumn{15}{|c|}{ Treatment cost } \\
\hline Plant growth regulators & 420 & 850 & 300 & 600 & 800 & 1,700 & 460 & 1020 & 385 & 870 & 800 & 1,700 & - & 250 \\
\hline Application cost & 600 & 600 & 600 & 600 & 600 & 600 & 600 & 600 & 600 & 600 & 600 & 600 & - & 700 \\
\hline \multicolumn{15}{|c|}{ Chemical cost } \\
\hline Pendimetheline 30\% EC & 800 & 800 & 800 & 800 & 800 & 800 & 800 & 800 & 800 & 800 & 800 & 800 & 800 & 800 \\
\hline Chlorpyriphos & 280 & 280 & 280 & 280 & 280 & 280 & 280 & 280 & 280 & 280 & 280 & 280 & 280 & 280 \\
\hline Coragine & 1,700 & 1,700 & 1,700 & 1,700 & 1,700 & 1,700 & 1,700 & 1,700 & 1,700 & 1,700 & 1,700 & 1,700 & 1,700 & 1,700 \\
\hline Harvesting and Threshing & 2,150 & 2,150 & 2,150 & 2,150 & 2,150 & 2,150 & 2,150 & 2,150 & 2,150 & 2,150 & 2,150 & 2,150 & 2,150 & 2,150 \\
\hline Tansport & 1,500 & 1,500 & 1,500 & 1,500 & 1,500 & 1,500 & 1,500 & 1,500 & 1,500 & 1,500 & 1,500 & 1,500 & 1,500 & 1,500 \\
\hline Total & 27,391 & 27,821 & 27,271 & 27,671 & 27,771 & 28,671 & 28,791 & 29,351 & 28,716 & 29,201 & 29,131 & 30,031 & 26,571 & 27,321 \\
\hline \begin{tabular}{|l}
$\begin{array}{l}T_{1}: 100 \% \text { RDF + Salicylic acid @ 50 } \\
\text { ppm }\end{array}$ \\
\end{tabular} & \multicolumn{2}{|c|}{$\begin{array}{l}\mathbf{T}_{3}: 100 \% \text { RDF + Ethrel @ } \\
100 \mathrm{ppm}\end{array}$} & \multirow{2}{*}{\multicolumn{2}{|c|}{$\begin{array}{l}\mathrm{T}_{5}: 100 \% \mathrm{RDF}+\text { Chlormequat chloride @ } \\
250 \mathrm{ppm} \\
\mathbf{T}_{6}: 100 \% \mathrm{RDF}+\text { Chlormequat chloride } @\end{array}$}} & \multicolumn{3}{|c|}{ 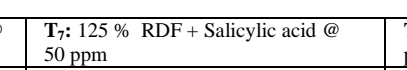 } & \multicolumn{2}{|c|}{$\begin{array}{l}\text { T: } 125 \% \text { RDF + Ethrel @ } 100 \\
\text { ppm }\end{array}$} & \multicolumn{3}{|c|}{ 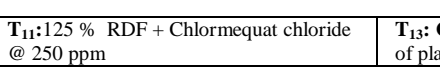 } & \multicolumn{2}{|c|}{$\begin{array}{l}\mathrm{I}_{13}: \text { Control }\left(\mathrm{C}_{1}\right) \text { : RPP, without spray } \\
\text { flant growht regulator }\end{array}$} \\
\hline \begin{tabular}{|l} 
ppm \\
$\begin{array}{l}\mathrm{T}_{2}: 100 \% \text { RDF + Salicylic acid @ } 100 \\
\text { ppm }\end{array}$ \\
\end{tabular} & \multicolumn{2}{|c|}{\begin{tabular}{|l|}
$T_{4}: 100 \%$ RDF + Ethrel @ 200 \\
ppm
\end{tabular}} & & & \multicolumn{3}{|c|}{$\begin{array}{l}\begin{array}{l}50 \mathrm{ppm} \\
\text { T: } 125 \% \text { RDF + Salicylic acid @ } \\
100 \mathrm{ppm}\end{array} \\
\end{array}$} & \multicolumn{2}{|c|}{$\begin{array}{l}T_{10}: 125 \% \text { RDF + Ethrel @ } 200 \\
\text { ppm }\end{array}$} & \multicolumn{2}{|c|}{$\begin{array}{l}\text { (250) ppm } \\
T_{12}: 125 \% \text { RDF + Chlormequat chloride } \\
@ 500 \mathrm{ppm}\end{array}$} & \multicolumn{3}{|c|}{ 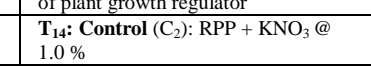 } \\
\hline
\end{tabular}


Table.3 Prices of inputs and outputs

\begin{tabular}{|c|c|c|c|}
\hline $\begin{array}{l}\text { Sl. } \\
\text { No. }\end{array}$ & Particulars & Unit & Price (₹) \\
\hline A & \multicolumn{3}{|l|}{ Inputs } \\
\hline 1 & \multicolumn{3}{|l|}{ Land ploughing } \\
\hline & Tractor cultivation & Per hr & 500 \\
\hline & Harrowing (bullock pair) & Per day & 1,200 \\
\hline 2 & Seed & Per kg & 66 \\
\hline 3 & FYM & Per $t$ & 500 \\
\hline \multirow[t]{4}{*}{4} & \multicolumn{3}{|l|}{ Fertilizer } \\
\hline & Urea & Per kg & 6 \\
\hline & SSP & Per kg & 8.6 \\
\hline & MOP & Per kg & 17.3 \\
\hline \multirow[t]{4}{*}{5} & \multicolumn{3}{|l|}{ Plant growth regulators } \\
\hline & Salicylic acid & Per kg & 1152 \\
\hline & Ethrel & $100 \mathrm{ml}$ & 187 \\
\hline & Chlormequate chloride (cycocel) & $25 \mathrm{~g}$ & 900 \\
\hline \multirow[t]{4}{*}{6} & \multicolumn{3}{|l|}{ Plant protection } \\
\hline & Chlorpyriphos & $500 \mathrm{ml}$ & 180 \\
\hline & Chlorantraniliprole & $50 \mathrm{ml}$ & 600 \\
\hline & Pendimethalin $30 \%$ EC & $700 \mathrm{ml}$ & 450 \\
\hline \multirow[t]{3}{*}{7} & \multicolumn{3}{|l|}{ Labour Wages } \\
\hline & Men & Per day & 318 \\
\hline & Women & Per day & 318 \\
\hline \multicolumn{4}{|c|}{ B) Outputs } \\
\hline 1 & Seed yield & Per q & 3600 \\
\hline 2 & Haulm yield & Per q & 75 \\
\hline
\end{tabular}

Note: Prices of the inputs as per University of Agricultural Sciences, Dharwad, Karnataka (India) norms used during the experimentation considered (November-2017)

Harvest index $(42.04$ and $42.86 \%$, respectively) recorded in control treatments $\mathrm{C}_{1}$ (RPP, without plant growth regulators) and $\mathrm{C}_{2}\left(\mathrm{RPP}+\mathrm{KNO}_{3} @ 1 \%\right)$ were on par to each other. Increase in the harvest index because of increase in economic and biological yield of the crop in general. It is mainly due to the beneficial effect of nitrogen, phosphorus and potassium nutrition on exploiting inherent potential of the crop for vegetative and reproductive growth and plant growth regulators improved source-sink relationship. Which lead to the increased productivity of soybean. Similarly these results are in agreement with the results of Devi et al., (2011), Vaiyapuri et al., (2012) and Shweta et al., (2014).

\section{Economic analysis}

The data on economic analysis of soybean as influenced by nutrient levels and plant growth regulators are presented in Table 1. Application of $125 \%$ RDF (50:100:31.25 kg $\mathrm{ha}^{-1}$ ) recorded significantly higher gross returns (₹ 80,436 ha ${ }^{-1}$ ), net returns (₹ 51,233 
$\mathrm{ha}^{-1}$ ) and $\mathrm{B}: \mathrm{C}$ ratio (2.75) as compared to 100 \% (40:80:25 kg ha ${ }^{-1}$ ) RDF (₹ 73,677 $\mathrm{ha}^{-1}$, ₹ $45,896 \mathrm{ha}^{-1}$ and 2.65, respectively), control $\mathrm{C}_{1}$ (₹ 61,546, ₹ 34,675 and 2.34, respectively) and $\mathrm{C}_{2}$ (₹ 64,967, ₹ 37,646 and 2.38, respectively). This was due to higher seed yield $\left(22.34 \mathrm{q} \mathrm{ha}^{-1}\right)$ and haulm yield $(26.66 \mathrm{q}$ $\mathrm{ha}^{-1}$ ) recorded with this treatment. These results are in conformity with the findings of Chaplot et al., (2013), Geeta and Radder (2015) and Yadravi (2015). Application of chlormequat choloride @ 500 ppm recorded significantly higher gross returns (₹ 89,128 $\mathrm{ha}^{-1}$ ), net returns ( $₹ 59,777 \mathrm{ha}^{-1}$ ) and B:C ratio (3.03), followed by ethrel @ 200 ppm (₹ $81,627 \mathrm{ha}^{-1}$, ₹ 53,191 $\mathrm{ha}^{-1}$ and 2.87) as compared to other treatments (Table 1). These results are in agreement with the findings of Devi et al., (2011), and (Sanjay, 2017). Among the interaction, application of $125 \%$ RDF + chormequat choloride @500 ppm recorded significantly higher gross returns ( $₹$ $94,745 \mathrm{ha}^{-1}$ ) and net returns ( $₹ 64,714 \mathrm{ha}^{-1}$ ), followed by $125 \mathrm{RDF}+$ ethrel @ 200 ppm (₹ $85,347 \mathrm{ha}^{-1}$, ₹ 56,146 ha $\mathrm{ha}^{-1}$ ) as compared to other treatment combinations, $\mathrm{C}_{1}$ and $\mathrm{C}_{2}$ (Table. 1). But, B:C ratio was statistically non-significant within the interaction. However, when compared to control, higher $\mathrm{B}: \mathrm{C}$ ratio (3.15) obtained with the application of $125 \% \mathrm{RDF}+$ chlormequat chloride @ 500 ppm followed by 125 RDF + ethrel @ 200 ppm (2.92). This was mainly due to higher seed yield of soybean. Similar results have been reported by Kalyankar (2008), Vaiyapuri et al., (2012) and Manpreet (2016).

In conclusion, the above results clearly indicates that application of $125 \% \mathrm{RDF}+$ chlormequat chloride@ $@ 500$ ppm at 25 and 40 DAS as foliar spray was found to improve the harvest index, net returns and $\mathrm{BC}$ ratio of soybean; followed by 125 \% RDF + ethrel @ $200 \mathrm{ppm}$. Thus, these treatments could be recommended for increasing the productivity of soybean.

\section{References}

Anonymous. 2017, USDA. http://www.pecad.fas.usda.gov/

Anonymous. 2018, Ministry of Agriculture and Farmer's Welfare, GOI. http://agricoop.gov.in/

Chaplot, P. C., Dungarwal, H. S., and Sumeriya. H. K., 2013. Comparative performance of soybean (Glycine max L. Merrill) genotypes at varying levels of nitrogen. Ann. Agric. Biol. Res., 18(3): 309-311.

Dass, A., Dey, D., Lal S. K., and Rajanna, G. A. 2018, Tank mix insecticide and herbicide application effects on weeds, insect-pest menace and soybean productivity in semi-arid northern plain of India. Legume Res., 42(3): 385-391.

Devi, K. N., Abhay, K.V., Maibam, S. S., and Naorem, G. S. 2011, Effect of bioregulators on growth, yield and chemical constituents of soybean (Glycine max). J. Agric. Sci., 3(4): 151159.

Donald, C. M., 1962, In search of yield. $J$. Aus. Int. Agric. Sci., 20: 171-178.

Geetha, G.P. and B.M. Radder. 2015. Effect of phosphorus cured with FYM and application of biofertilizers on productivity of soybean (Glycine $\max \mathrm{L}$. Merrill.) and phosphorus transformation in soil. Karnataka J. Agric. Sci., 28(3): 414-415.

Gomez, K. A., and Gomez A. A. 1984, Statistical Procedure for Agriculture Research, $2^{\text {nd }}$ Ed., John Willey and Sons, New York, p. 680.

Kalyankar, S. V., Kadam, G. R., Borgaonkar, S. B., Deshmukh, D. D., and Kadam, B. P. 2008, Effect of foliar application of growth regulators on seed yield and yield components of soybean (Glycine max L.). Asian J. Biol. Sci., 3(1): 229230.

Khan, W., Balakrishnan, P., and Donald, L. S. 
2003, Photosynthetic responses of corn and soybean to foliar application of salicylates. J. Plant Physio., 160: 485492.

Manpreet, J. 2016, Growth regulation and defoliation studies for source-sink optimization and synchronized maturity in soybean (Glycine $\max$ L. Merrill). Ph. D Thesis, Punjab Agric. Univ., Ludhiana.

Manu, S. M., Halagalimath, S. P., Biradar, B. D., and Chandranath, H. T. 2020, Influence of nutrient levels and plant growth regulators on relative chlorophyll content (SPAD value), days to $50 \%$ flowering and nodulation of soybean (Glycine max). Intl. J. Chemical Stud., 8(1): 2079-2081.

Nahar, B. S., and Ikeda T. 2002, Effect of different concentrations of figaron on production and abscission of reproductive organs, growth and yield in soybean. Field Crop Res., 78: 41-50.
Sanjay, W. 2017, Effect of plant growth regulators on morphological and physiological parameters of soybean (Glycine max L. Merrill). M. Sc. (Agri.) Thesis, Rajmata Vijayaraje Scindia Krishi Vishwa Vidyalaya, Gwalior, Indore (M.P.) .

Shweta, G., Jain M. P., and Atul, G. 2014, Effect of nitrogen and plant growth regulators on soybean [Glycine max (1.) Merrill] under late sown conditions. Soybean Res. 12 (Special Issue): 184187.

Vaiyapuri, K. M., Amanullah M., and Rajendran, K. 2012, Growth and yield of soybean as influenced by nitrogen and growth regulators. Madras Agric. J., 99(1-3): 79-80.

Yadravi, M. 2015, Effect of time and method of application of varied levels of nitrogen in soybean. M. Sc. (Agri.) Thesis. Univ. Agric. Sci., Dharwad. Karnataka (India).

\section{How to cite this article:}

Manu, S. M., S. P. Halagalimath, H. T. Chandranath and Biradar, B. D. 2020. Effect of Nutrient Levels and Plant Growth Regulators on Harvest Index and Economics of Soybean (Glycine max). Int.J.Curr.Microbiol.App.Sci. 9(03): 890-897. doi: https://doi.org/10.20546/ijcmas.2020.903.104 